\title{
The Content Of Elementary And Higher Education In 8th - 9th Century Frankish Monasteries
}

\begin{abstract}
Seda ERKOÇ*
Abstract

Along with the Carolingian ${ }^{1}$ Social Renovations realized thanks to the reformist zeal of Charlemagne, especially concentrated on the intellectual background of the Clergy which was highly degenerated and corrupted, a new educational aspect was gained both in Carolingian court and in monastic circles. Charlemagne met the Irish scholar Alcuin on the way back home in Parma on one of his visits to Rome and invited him to his court along with some other European scholars. Alcuin contributed a lot to the educational organization of the clergy, to the instruction of the noble and lay boys and girls. Carolingian monasteries were especially held in this study because it was the only place education could be found in an institutionalized level in the Frank Empire at the time apart from the Palatine School of Charlemagne. Charlemagne and Alcuin held the reconstruction of intellectual life so seriously that they issued numerous charters on education both for the clergy and for the lay boys in pariochal areas. Alcuin included Liberal Arts (Trivium and Quadrivium) to the Carolingian educational processes along with the Latin, computus and basic arithmetic teachings. In this study one can found the general content of elementary and higher monastic education in Carolingian Monasteries following an introduction of the structure of Carolingian monasteries at the time.
\end{abstract}

Keywords: Carolingian Monasteries, Liberal Arts, Carolingian oblates, St.Gall, the Rule of Saint Benedict.

\section{8. ve 9. Yüzyıl Frank Manastırlarında Orta ve Yüksek Öğretimin İçeriği}

Öz

Özellikle ruhban sınıfının hayli dejenere olmuş ve yozlaşmış durumdaki entellektüel altyapısına odaklanmış bir şekilde, Şarlman'ın reform tutkusu sayesinde gerçekleştirilen, Karolenj² reformları ile birlikte hem Karolenj Hanedanlığının sarayında hem de manastır çevrelerinde yeni bir eğitsel bakış açısı kazanıldı. Şarlman İrlanda asıllı bir bilgin olan Alcuin'e Roma'ya düzenlediği gezilerden birinden dönerken Parma'da rastlamış ve bir kaç diğer Avrupalı bilginle birlikte onları sarayına davet etmiştir. Alcuin Ruhban sınıfının, asil ya da köle sınıfından olmayan kız ve erkek çocuklarının eğitim ortamlarının düzenlenişine çok katkıda bulunmuştur. Bu çalışmada özellikle Karolenj manastırları ele alınmış ve incelenmiştir çünkü o dönemde eğitime Frank İmpratorluğu'nda, Şarlman'ın Saray Okulu'ndan başka kurumsallaşmış

\footnotetext{
* Sakarya University, Institute of Education, Higher Education Department, sedaerkoc83@gmail.com

${ }^{1}$ A Frankish noble clan which started to reign in Frankland in 7th century. It means "people descending from Charles.

2 7. Yüzyılda Frank ülkesinde hüküm sürmeye başlayan soylu bir klan. “Charles'ın soyundan gelen” anlamı taşımaktadir.
} 


\begin{abstract}
bir seviyede rastlanılabilecek tek yer bu manastırlardı. Şarlman ve Alcuin entellektüel hayatın yeniden düzenlenişini o kadar ciddiye almışlardır ki hem ruhban sınıfı hem de kilise semtlerinde yaşayan ve bu sınıfına dahil olmayan çocukların eğitimi üzerine çok sayıda nizamname yayınlamışlardır. Alcuin Karolenjlerin eğitsel süreçlerine Latince, temel hesaplamalar ve aritmetik öğretimi ile birlikte Beşeri İlimler'i (Trivium \& Quadrivium) de dahil etmiştir. Bu çalışmada, dönemin Karolenj Hanedanı'na ait manastırlarındaki yapının tanıtılmasını takiben bu manastırlardaki ruhban eğitiminin orta ve yüksek seviyelerindeki genel içerik incelenmiştir.
\end{abstract}

Anahtar Kelimeler: Karolenj Manastırları, Beşeri İlimler, Karolenj Manastırlarında Öğrenciler, St. Gall Manastırı, Aziz Benedict Kuralları.

\title{
1. INTRODUCTION
}

There are many works on how the monasteries in the early middle ages educated their oblates. But how the organization of teaching was in elementary and higher levels is not that specifically dealt in details. In the early middle ages; there were many monasteries in different parts of Europe and many had their own system of teaching, along with the Rules of Saints, Church Fathers' teachings, various epistles, teachings orally transmitted, chants, etc. Carolingians were especially concentrated on monastic education and monasteries were not only holly educational centers but also functioned as complexes economically self-sufficient. But the most important aspect to be underlined is their educational characteristic no matter how religion-oriented it is. The aim of this study is to specify these characteristics and present the educational environments in a certain array and can be read as a basic and simple guideline to how these monastic circles performed their teaching exercises in the aforementioned centuries at the high-time of the Frankish realm.

\subsection{Method}

This study has a descriptive character; the interpretations of the author depends on various works under related topics but Grotans' Reading in Medieval St. Gall (2006), Hildebrants' The External School in Carolingian Society (1992), Sullivan's The Gentle Voices of Teachers: Aspects of Learning in the Carolingian Age (1995), Cunningham \& other's Culture and Values: A Survey of the Western Humanities (2013), De Jong's In
Samuel's Image: Child Oblation in the Early Medieval West (1996) and McKitterick's Carolingian Culture: Emulation and Innovation (1994) are especially at the center of the study as their writers' profound knowledge of the period can be observed in their other works under various topics in the related literature. These works are especially benefitted from to present the content of the medieval Carolingian monastic curriculum. Most of the tables are especially formed by reading the tables in Grotan's Reading in Medieval St. Gall as it has a very qualified array of descriptive tables on the content of education in St. Gall. St. Gall can be depended on to make some solid generalizations as it was a very characteristic and prominent abbey at the time as others like Fulda, Metz and St. Dennis, etc. Verhulst's The Carolingian Economy (2002), Bernhardt's Itinerant Kingship and Royal Monasteries in Early Medieval Germany, c. 9361075 (2002) and Riché's Daily Life in the World of Charlemagne (1978) were especially cited to give figures on the economical and demographic qualities in Carolingian monasteries as it is important to know the avarage or approximate population and economical well-being of Carolingian monasteries to have an idea about their other fucntions and how they served not as only educational centers but also as a sociological phenomenon at the heart of the early middle ages. 


\subsection{Monasticism as a Concept \& Overall Info on Carolingian Monasteries in 8th and 9th Centuries}

Having a look at the literature it is highly probable to come across with some typical statements on the origin and the nature of Christian monasticism: "The concept of monasticism, the withdrawal from the corruption of everyday life in order to contemplate things spiritual, originated in $4^{\text {th }}$ century Egypt, where Christian hermits led solitary lives in the desert wilderness. At about the same time, the idea developed that groups of monks might live together communually, and both the hermitic and communal forms of monasticism spread rapidly from Egypt to the edges of the Christian world" (Moffett \& Others, 2003: 125 ). "The original monks were hermits living in isolation -- the word monk was derived from the Greek for 'one who dwelt alone'. However, some hermits began to live in communities. By the early fourth century the monastic movement had developed in the Egyptian desert, and from this source it spread throughout the Christian world" (Greene, 1992: 1). "The ideals of monasticism were summed up in the three ideals of chastity, poverty, and obedience. The primary characteristic of monasticism is denial" (Cordasco, 1976: 24).

Monasticism occupies a central but anomalous place in the history of the Middle Ages. Monks and nuns were the religiosi ${ }^{3}$, they practiced the purest Christianity, a life of prayer and work embracing poverty, chastity, and obedience. From monastic colonies such as Canterbury and Fulda much of Europe was evangelized ${ }^{4}$, and in Ireland abbots supplemented or superseded bishops in providing a framework for ecclesiastical organization. The work of teach-

${ }^{3}$ Plural form of "religioso" which means religious or monk in Italian. It is a word descended from Latin. ${ }^{4}$ Christianized. ing letters and coping manuscripts in monasteries preserved the legacy of classical culture through the political and social dislocations of the early medieval period and inspired great artistic achievements in illumination and metalwork. Abbeys became the centers of huge and widely disperced estates whose leaders were important figures in the world they renounced (Venarde, 1999: 1). Monks educated in the cloister might be called to court service and eventually made bishop; courtiers educated clerically at court might become abbots or bishops. A virtually complete interchange among these three dominant centers of intellectual and civil/administrative life seems to be one result of the universality of education (Jaeger, 1994: 27). As can be deduced reading upon these lines it was a highly prestigious social attribution to be a part of the clergy and it was through monastic education. So monasteries were significant self-reliant institutions that mattered both for the Empire and the individuals within the related part of the society who plans a career in clergy. Carolingian clan valued monasteries a lot and they were integral part of the Empire in socio-cultural and economical sense. Hildebrant (1992: 51) writes that there are three main reasons why monasteries were that important for Carolingian clan. Three reasons are:

- Monasteries were a part of the family interest or wealth and many Carolingian mayors like the first Carolingian Arnulf ${ }^{5}$ pursued a church career first becoming bishop and then sainted.

- Monasteries were considered educational institutions for recruiting allies or administrators.

${ }^{5} 7$ th century Frankish monarch. 
- The wealth and the land associated with monasteries become crucial prizes to be awarded loyal supporters.

Looking at these reasons Hildebrant claimed, we can see that monastic life was closely intertwined with the economic aspect of the empire along with the administrational one. So it wasn't something unusual to have a desire to promote within the body of Abbeys; to become abbot or abbesses in order to acquire wealth and prestige. McKitterick writes (1994: 623) that monasteries were prominent in the overwhelmingly rural landscape, harboring hundreds of people; their economic, social and cultural impact has been compared to that of towns in a later age.

Bishop churches and abbeys, whose real property in the ninth century was equally important, had built up through gifts of kings, aristocrats and ordinary people, an immense patrimony mostly consisting of manors. The abbey of St Germain-des-Prés had 25 villae $^{6}$ listed in the famous polyptych of abbot Irmino from c. 825-9, which was a minimum. Together they represented about 30,000 hectars of land and woods. Smaller abbeys had ten to twenty villae with several hundreds of hectares of arable land each (Verhulst, 2002: 32). Nevertheless, scattered evidence from the ninth century and good documentation from the tenth and early eleventh centuries indicate that a similar type of monastic property division materialized slowly in the east Frankish realm and became firmly established during the German imperial period. The economic, political and religious conditions that instigated and, in some ways, presupposed the assignment of special conventual endowments and the eventual divisions of monastic property did not exist to the same

\footnotetext{
${ }^{6}$ House, estate.
}

extent east of Rhine ${ }^{7}$. Thus, development was slower there. For instance, in comparison with the west Frankish monasteries, those in the east Frankish realm-with the possible exception of Lorsch and St. Gall and, perhaps, Fulda, Hersfeld and Corvey- did not at this early date possess property and assets in such abundance that the abbot had a huge excess to grant in benefice or to secularize, and thus endanger the needs of the monastery and the congregation (Bernhard, 1993: 110). So there was a difference and unbalance between the economical power in two parts of the realm which signifies that the abbeys and churches were one of the main economical sources themselves and we already know that an abbey was very easily able to be economically self-sufficient and could save money as after the inversion of St. Gall's plan into to monastic realm, an abbey had many social unit like a tailor, market, blacksmith, etc.

Chroniclers who wished to praise some particular monastery tended to puff up the members with references to hundreds of monks. "Thus Jumieges was said to hold 900 monks, although a list from the year 826 contains only 114 names. As we have seen, the dormitory of Saint-Gall made provision for 70 monks. Some 72 monks can be counted for Ferrieres; 70 at Saint-Wandrille, and 84 at Charroux. Adalhard of Crobie claimed 300 monks for this monastery with 150 auxillaries. At Saint-Bertin there were 60 religious and 112 servants. In 832, under Hilduin, there were 150 monks at SaintDenis. Some 120 religious are known to have been at Saint-Germain-des-Pres in 820. Therefore, except for Corbie and Saint-Riquier, where the number of monks reached 300, the numbers for the great monasteries range between 70 and 150 , which is modest enough. To this number

\footnotetext{
${ }^{7}$ A European river flowing through present day Germany, Ausrtia, Switzerland, France, Netherlands, Luxemburg, Italy, Liechtenstein.
} 
we must add servants, temporary domestic personnel, the poor, and the foreigners who resided briefly in the hostelry. Thus the population of a monastery was very unstable, but it rarely surpassed a thousand person" (Riché, 1978: 40). As can be deduced from all these, though changeable, monasteries were prominent institutions with a solid population in which education is held by a solid number of monks and monastic students.

In 787 Charles addressed a capitulary to the abbot of Fulda, ordering that in all monasteries and bishops' houses there should be study, and "let those who can, teach." In 789 he enacted: "Let the ministers of God's altar...Collect and associate with themselves children not only of servile condition, but free born: and that there may be schools for reading -boys, let them learn psalms, notes, chants, the computus and grammar, in every monastery and bishop's house." (Deanesly, 1969: 57) Carolingian capitularies on education do not make distinctions between cathedral and monastery schools; they enjoin the same education on both (Jaeger, 1994: 27). Actually, the monasteries were the sole schools for teaching; they alone offered professional training; they preserved books; they were the only libraries; they produced the only scholars; they were the sole educational institutions of the period. By the $10^{\text {th }}$ century, they developed both inner monastic schools for those intending to take the vows (oblati), and outer monastic schools for those not so intending (externi). Although instruction in both schools was meager, it provided for reading, writing, music, arithmetic, religious observation, and rules of conduct (Cordasco, 1976: 24). Horn and Born, who posit two separate schools, argue that the scola interior was essentially confined to elementary learning whereas the scola exterior quickly developed into a school for advanced study. This view is supported by a distinction made by
Hildemar $^{8}$ in his Expositio Regulae, namely that monastic schools offered training in monastic disciplines such as chant, reading and basic arithmetic, whereas ecclesiastical schools taught the seven liberal arts. Riché notes that some Carolingian masters use the term coined by Gregory the Great ${ }^{9}$ "exteriora studia" to refer to a study of the seven liberal arts as opposed to theology (Grotans, 2006: 58). Those exterior schools were small schools within the complex of monasteries or cathedrals and they served for the children of the villagers or of the public of the county. As one can understand from the enactments of Charlemagne, he was the first emperor ever to enable the secular education take place around his kingdom in the middle ages. To make it more solid, he sent decrees and arranged capitularies throughout the kingdom. The charters demanded there would be no discrimination on who can make use of the education provided.

There used to be adult novices and oblates if we need to categorize the age group into the most basic level. According to the Rule of Saint Benedict which was accepted in the Carolingian monastic circles under the reign of Charlemagne, to be able to become an oblate or a conversi, in other words; an adult novice, there were some criterion like age (15) and voluntariness. Child oblates needed to desire it to enroll in the monastic education which means they could not be compelled to start a monastic educational life. About that De Jong (1996: 61) writes on a capitulary issued on the Benedictine monasticism as 'no one may be forced against his will to take the vow, adds that children were referred differently than the adult ones so the two belonged to different categories. He moves on the change pointing out to the council of Mainz in 813 and quotes again a criteria: 'except at the legitimate age and of their free will, or with the permission of their lord' which

\footnotetext{
${ }^{8}$ Hildemar of Corbie, monk, (c.821 or 826- 850).

${ }_{9}$ Saint Gregory the Great, he has numerous writings which regulates monastic affairs. (c. 540- 604) .
} 
shows that children are now in line with the adult ones.

Teachers, the magistri, were so occupied and had lots of things to do within a day of teaching. They had both educational and supervising tasks on novices and oblates. The job of the magister was never-ending. Not only was he in charge of the intellectual welfare of the pupils, but also of their spiritual well-being. Overwhelmed by the amount of work, and perhaps wishing to spend more time with their books, some teachers tried to evade other monastic duties (Grotans, 2006: 66). A magistri needed to be 25 at least to teach. The older ones teaching were called the magistri, some of whom could be specialized in one, some or most of the liberal arts while there were others whom could be called as semi-magistri. Teachers were supposed to be at least 25 years old, although monks often taught at a younger age in the role of teaching assistants, called semimagistri (Grotans, 2006: 65). The novices an oblates wore monastic garb, whereas the pupils of the outer school wore the white robe of the secular priest. But the discipline to which the latter were subjected was quite as rigorous as that of the cloisters. There were wardens (circatores) whose duty it was to keep the order. They were generally old monks and their vigilance was unceasing. They went on their rounds at all hours to see that everyone was doing his task; they supervised both the young boys and their elders. If they detected any disdemeanour they silently wrote the name of the culprit on their wax tablets and brought the matter up the next morning in chapter (Clark, 1926: 94).

We can state that although they were child oblates, they could get higher in rank in respect to the other monks. An oblate might be higher in rank than another who is older than him. So age is not a ground for competence and effi- cacy. It was up to how much time was spent within the monastery not the age. "Whoever entered the monastery first could count on a higher position in the order of monks. In all situations in which the community met in its entirety, 'age should not determine the rank'. In the refectory and the oratory, therefore, child oblates might occupy a better place than adult novices who had joined the monastery after them (De Jong, 1996: 145-6).

\section{2.“ECCLESIASTICAE DISCIPLINAE" In CAROLINGIAN MONASTERIES}

\subsection{Elementary Tutelage}

In Charlemagne's Empire, the lingua franca was the lingua latina. The caretakers of literary culture were monks and clerics, many of whom were also politically active at the royal courts. They were entrusted with the care and propagation of the written word, primarily of God but also of classical authors, which provided an educational framework and normative model for written Latin that was soon to be adapted by Church and government for their own purposes (Grotans, 2006: 15). This can be shown as reason why it was so important for a novice in a monastery to learn and utilize that language at the highest level. During this period, computus was a central part of religious academic study, especially within the Carolingian revival of learning. In Bede ${ }^{10}$ s time, there was no syllabus as such for monks; instead mimesis of their seniors provided monks' basic training in all practical and doctrinal matters in their communal lives. Charlemagne instituted a curriculum for both monasteries and cathedrals that put computus on the map of European continental scholarship. The curriculum in-

\footnotetext{
10 Anglo-Saxon monk, (c.672/673- 735), well known as an author and scholar, and his most famous work, Historia ecclesiastica gentis Anglorum., famous for his works in computus as well. Alcuin was his instructor.
} 
cluded grammaticum (reading), notas (writing), cantus (music), psalmos (liturgy) and compotum (computus) (Carlbach, 2011: 10).

Reading \& Writing Latin: Latin was the language of administration, the church learning and even for those who spoke Latin as their native language, instruction in the complexities of its grammar was necessary (McKitterick, 1994: 174). Instruction in Latin grammar was provided from the grammars of Donatus ${ }^{11}$ and Priscian $^{12}$. There were manuals for students which depicted parts of speech. They were largely in dialogue form and thought this way (Cross \& Livingstone, 2005: 293). Tutelage for writing in Latin consisted of repetitious writing on wax tablets for practice. And what they said and sang were the words of God and words in praise of God, words that had to be pronounced correctly to be effective (Sullivan, 1995: 115). Students learned the letters in combination and separately. Reading Gospels, Psalms, Psalters and the Bible was the basic necessity in the elementary level. Every educational sum of data needed to be memorized and memorization was almost the basic or the core technique used in theological learnings. Students were even required to memorize the interpretations of the Psalms and the Gospels. The more a student had these in memory the wiser and able he was considered. They did it though constant drills and repetitions. His progress would be charged with his competence in reciting the Psalters.

Arithmetic through Computus: During the ninth century, under the influence of Carolingian educational efforts, ecclesiastical computus became one of the essential components of

11 Aelius Donatus, known as rhetorician and a Grammarian in Rome in the mids of c. 4th century AD.

12 Priscianus Caesariensis, Latin grammarian in Rome inc. $500 \mathrm{AD}$. clerical instruction. The diverse collections of astronomical traditions began to be manipulated in new ways, transposing the discipline of antique Latin astronomy into a Christian conception of time.' Monastic reform legislation and the dissemination of classical astronomical texts on the constellations of planets played an important role in the transformation of monastic traditions of reckoning time, while Carolingian writers like Hrabanus Maurits encouraged the instruction of a computus that had, since Bede, included elements of ancient astronomy derived from authors ranging from Pliny to Isidore of Seville (Corradini \& Others, 2003: 270).

Future priests and monks would often draw on the practical skill of manipulating numbers in the performance of their sacred and mundane duties. They had to know how to calculate dates of holy days such as Easter and the equinoxes and how to use the various tables that made that task easier. Collection of the tithe and its distribution into fourths also required arithmetical learning, as did calculation of harvests from fields or receipts from peasants, which often fell to clergymen. Carolingian masters were at their cleverest when attempting to teach arithmetical reasoning. A series of "story problems" attributed to Alcuin would not be unfamiliar to modern students. "Suppose," one propositi ${ }^{13}$ suggested, "that three men are traveling together, each with his own sister. When the six travelers came to a river, they found a boat that could carry only two persons at a time over the river. One of the men lusted after the sisters of his friends. How did they manage the crossing and at the same time preserve the girls from harm?" (Sullivan, 1995: 117).

\footnotetext{
${ }^{13}$ A name or person from whom a line, a statement or a quotation descended.
} 
Chant: One of the main areas to study for oblates was to study music and chants. Musical curriculum was like the core of elementary phase of an oblate's education. Along with the tenth and eleventh centuries, oblates were expected to recite or memorize a great many Psalms and hymns, litanies, reading texs, learn how to read them by heart with correct intonation and sing both simple and fairly complex examples of chants as a genre. Boys were assigned an ever greater number of chants and readings. Learning these chants and readings, as well as many others, seems to have occupied every free moment of the day. The training process necessarily constituted a monk's entire education, at least until he mastered the most essential liturgical material. The first chants to be learned were the Psalms, canticles and hymns (Ferzoco \& Muessig, 2001: 8). Since the choice of Psalm tone and differentia depended on the mode of the antiphon chanted before and after the Psalm, beginning students had to learn the church modes, a system of tonal organization adopted in the Carolingian period that provided parameters for the classification and memorization of chants (Ferzoco \& Muessig, 2001: 13).

Music was the theoretical study of scale, proportion, the harmony of the universe, and "music of the spheres." Music in this period was distinguished from cantus, which was the practical knowledge of chants and hymns for church use (Cunningham \& Others, 2013: 248). The Psalms are songs, and while learning to read them, students learned to sing them and thus received their introduction to chant. The observation of the daily office made chant a lifelong practice. Neumic notations, the early medieval system of assigning graphic values to melody, appear as apparently random jottings in many nonmusical manuscripts, thus suggesting that students thought about or practiced their lessons away from the choir (Sullivan, 1995: 116).

\subsection{Advanced Tutelage: Liberal Arts}

By the time of the Caroligians, especially with the efforts of Alcuin, Liberal Arts got into the curriculum of Carolingian higher studies and education and naturally into the monastic circles as well. From that period they got into a character like Christianized Liberal Arts. They had become a part of the new Carolingian educational curriculum which was started up to start a renovation on the education of the clergy. So it was inevitable that it was highly vocational or occupational in character, leaning towards the theological aspect.

The trivium comprised grammar, rhetoric, and dialectic. Pupils then moved to the Quadrivium of the interconnected subjects of arithmetic, geometry, music, and astronomy. (Cross \& Livingstone, 2005: 293). The term Trivium means, "where three roads meet" while the term Quadrivium means "where four roads meet." So important was the use of trivium in all areas of learning that a students wasn't permitted to begin study of the quadrivium until he had sufficiently mastered the trivium. The conceptual basis of education was thus understood as a process of synthesis, or reasoning, by which students learned how ideas and subjects integrate and interact with one another, and by which they learned how to synthesize subjects on their own (Barber, 2008: 96). Not only were the trivium and the quadrivium frequently separated and latter often not taught at all between the seventh and the eleventh centuries, but within the trivium itself the study of grammar and rhetoric received far more attention than logic. This is partly the result of the emphasis that early medieval culture placed upon literary training for the study of sacred texts and partly the result of the char- 
acter of materials available for the study of logic (Dales, 1973: 13).

Grammatica began with lectio, which provided the foundation for all further textual interpretation, since through it the letters (litterae) of a text were transformed through a synthetic recognition into syllables, words and finally into connected discourse (oratio). In its preliminary phase, praelectio, reading included deciphering the graphemes on the manuscript page, construing words and determining their syntactic relationships, defining their meaning and finally reciting the text aloud according to a correct understanding of it. This last step was particularly important, for it was only through actual vocal performance that a text became discourse and was realized as such. Thus the spoken word (as based on the written text) became the object of further analysis, which included interpretation (enarratio), correction (emendatio) and criticism (iudicium) (Grotans, 2006: 26). To be able to comprehend the subdivisions of the trivium we can have a look at the details of grammatica and rhetoric as in the following charts.

*Orthography

\begin{tabular}{lllll}
\hline Praelectio & 1. Lectio & 2. Enarratio & 3.Emendatio & 4. Iudicum \\
& Rules for reading
\end{tabular}

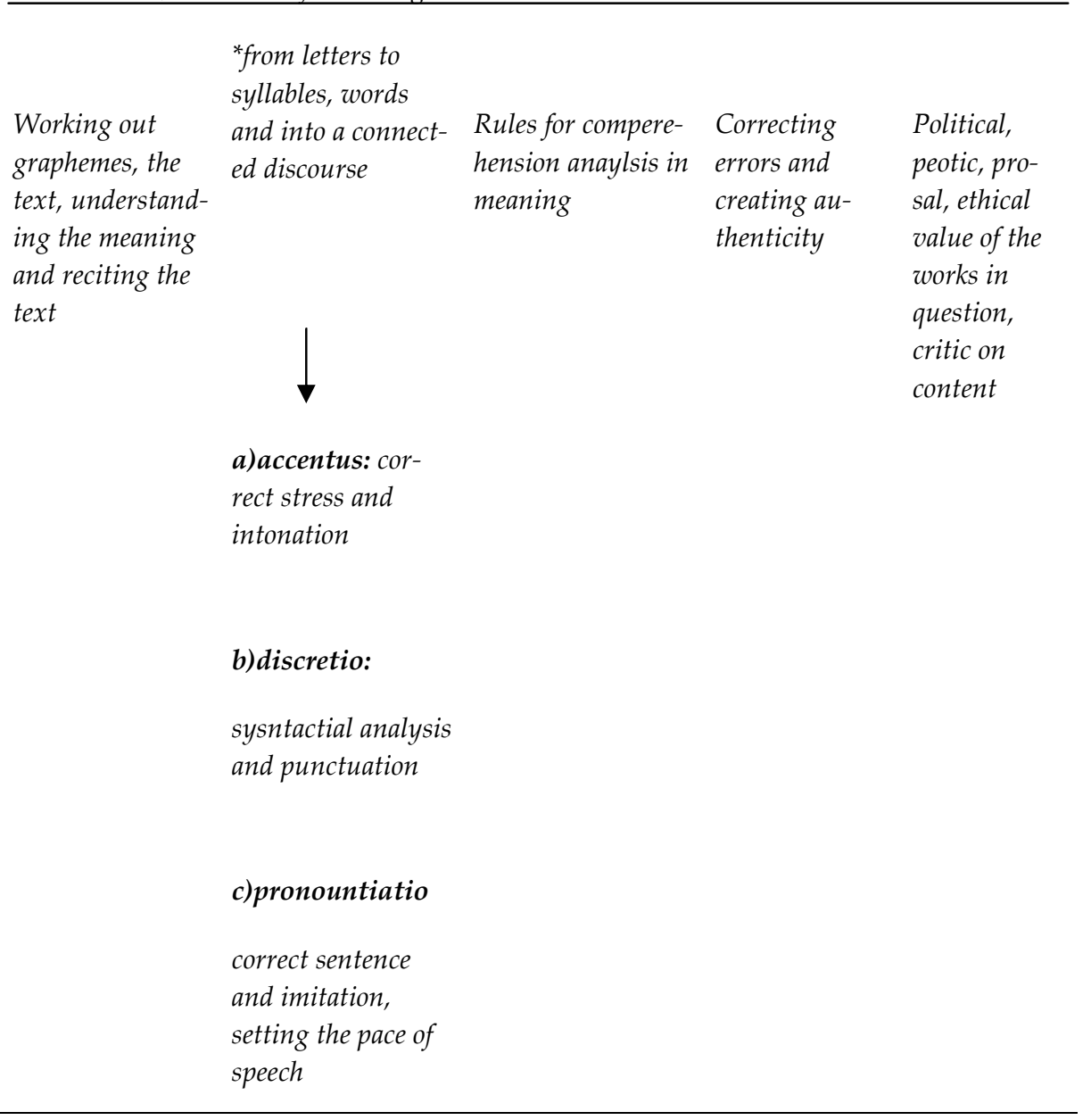

How to write

and speak

correctly,

especially

Latin. Stu-

dents worked

by Treatises

on orthogra-

phy.

(Quintilian,

Alcuin, Not-

ker and Hra-

banus had

orthographic

works on

which the 


\author{
d) modulatio: \\ correct modulation \\ of the tonation, of \\ the voice
}

Carolingian

scholars

taught.)

\section{* Interpretation}

Figure 1: Arte Grammatica

In ancient Rome Rhetoric was the first of the liberal arts in order of dignity; in Gaul the Schools of Rhetoric survived the fall of the Empire. But within the walls of mediaeval monasteries, where silence was prized more highly than speech, the art of the orator was felt to be unnecessary, if not positively dangerous. Isidore of Seville declared that the word of God did not need the verbal display of the rhetori- cian. A few generalities based on the theoretic treatises of classical writers formed the stockin-trade of the mediaeval teacher. It was generally considered sufficient to be acquainted with the terminology of Rhetoric, to be able to distinguish the three kinds of eloquence, to have some idea what was meant by inventio, dispositio, and elocutio, to know the six parts of an oration, and so on (Clark, 1926: 114).

\begin{tabular}{|c|c|c|c|c|}
\hline 1. inventio & 2. dispositio & 3. elocutio & 4. actio & 5. Memoria \\
\hline $\begin{array}{l}\text { Collecting the neces- } \\
\text { sary knowledge about } \\
\text { the speech }\end{array}$ & $\begin{array}{l}\text { Organizing the data } \\
\text { gathered, forming the } \\
\text { structure of the speech. }\end{array}$ & $\begin{array}{l}\text { Providing text with } \\
\text { elegance and gran- } \\
\text { deur: style of the } \\
\text { speech }\end{array}$ & $\begin{array}{l}\text { Delivering, per- } \\
\text { forming the } \\
\text { speech, actualiz- } \\
\text { ing it. }\end{array}$ & $\begin{array}{l}\text { Reciting, learning it } \\
\text { by heart. }\end{array}$ \\
\hline $\begin{array}{l}\text { Verse, Quis, Quid, } \\
\text { Ubi, Quibus Aux- } \\
\text { iliis Cur, Quomodo, } \\
\text { Quando? } \\
\text { (Who, What, Where, } \\
\text { By Which Means, } \\
\text { Why, How, When?) }\end{array}$ & & $\begin{array}{l}\text { a) Genus judiciale: } \\
\text { concetrates on past. } \\
\text { More defense less } \\
\text { accusation. } \\
\text { b) Genus delibera- } \\
\text { tivum: } \\
\text { concetrates on fu- } \\
\text { ture. More persua- } \\
\text { sion less discussion. } \\
\text { c) Genus demon- } \\
\text { strativum: deals } \\
\text { with present most. } \\
\text { Concentrates on the } \\
\text { beauty of the text, } \\
\text { easthetical. }\end{array}$ & & \\
\hline
\end{tabular}


The study of grammar would set out the rules of writing, while dialectic would help distinguish true from false propositions (Cunningham \& Others, 2013: 248). Dialectic, in other words; logic was also a part of the medieval Seven Liberal arts which was originally nine at total including the Philosophy previously. Dialectic included subranches like genus, species, differentia, property and accident. The four mathematical arts, called the quadrivium, usually received only superficial treatment in the Carolingian schools. Because the acquisition of the ability to read and write in Latin was a great task in itself, emphasis was placed on the literary subjects of grammar, rhetoric and dialectic with the Carolingians named trivium (Lynch, 2013: 93). New texts for teaching the trivium were provided by Carolignian scholars like Alcuin. By contrast study of the quadrivium was limited. Arithmetic was learned in the context of computus, music as a means to augment the impact of the liturgy, astronomy as a means to detect the providential plan in the movement of the planets, and geometry hardly at all since it was difficult to apply usefully in the context of Christian learning. (McKitterick, 1994: 37).

\section{PROMINENT TEXTS AND CLASSICAL}

\section{WORKS STUDIED IN CAROLINGIAN MONASTERIES}

There was, however, little fresh or original work done on these subjects (Copleston, 1950: 110). Few books were available, and writing was done on slates or waxed tablets, because parchment was expensive (Cunningham \& Others, 2013: 248). The students, who learned the elements of reading, writing, chant, and computus were ready for their own crossing into the world of the liberal arts. Here the terrain got technical very fast (Sullivan, 1995: 117). While gliding into Liberal Arts Carolingian monastic students studied with Martianus
Capella ${ }^{14}$ s Marriage of Philosophy and Mercury, Isodore of Sevilles ${ }^{15}$ 's Etymologies and De natura rerum, Cassiodorus's Institutiones. In grammar, some of the texts of the Latin grammarian Priscian might be studied and then applied to passages from Latin prose writers. (Cunningham \& Others, 2013: 248). The larger cultural work performed by grammatical can be observed in the status given to writing and texts in Bede's Historia ecclesiastica. The Historia ecclesiastica differs to written records as the primary sources of history and presents oral report only when written records are lacking and when contemporary history, yet untextualized, must be committed to writing (litteris mandare) (Irivine, 2006: 273). In rhetoric, the work of Cicero $^{16}$ was studied, or Quintilian ${ }^{17}$ 's Institutio oratoria if it was available. For dialectic, some of the work of Aristotle might be read in Latin translation of Boethius (Cunningham \& Others, 2013: 248). Evidence of dialectical reasoning in the Libri Carolini ${ }^{18}$ and in the writings of Alcuin, Fridugisus, John Scottus, Heiric and Remigius of Auxerre, Ratramnus and Hadoard of Corbie, and many others is incomprehensible without acknowledging dialectical studies in the schools. Some of these masters taught dialectic, and their lessons have survived in the form of glosses and the dicta. Students practiced formal syllogistic exercises on the flyleaves of manuscript (Sullivan, 1995: 123). In arithmetic, multiplication and division were learned, and perhaps there was some practice on the abacus,

\footnotetext{
${ }^{14}$ Latin Prose writer and developer of Liberal Arts in 5th century.

${ }^{15}$ An archbishop in Seville in the 6th century, he wrote the first genre that can be named as an encyclopedia.

${ }_{16}$ Marcus Tullius Cicero, (c.106-43 BC), Roman politician, orator, lawyer, constitutionalist.

${ }_{17}$ Marcus Fabius Quintilianus, (c.35-100 AD), Hispanic rhetorician.

${ }^{18}$ A book written by the command of Charlemagne and consists of the conclusions of the Second Council of Nicaea held in 787.
} 
because Latin numerals were clumsy to compute with pen and paper. Arithmetic also included some practice in chronology, as students were taught to compute the variable date of Easter. They would finish with a study of the allegorical meaning of numbers. Geometry was based on the study of the Greek mathematician Euclid $^{19}$. Astronomy was derived from the Roman writer Pliny the Elder ${ }^{20}$, with some attention to Bede's work. (Cunningham \& Others, 2013: 248). Latin versions of Aristotle ${ }^{21}$ s $D e$ categoriis and De interpretatione and other compiled treatises may also have been read at the early intermediate level (Grotans, 2006: 73). There was also a literary type called epic vitae. Epic vitae were read in the classroom. Poems, both Classical and Christian, provided the fundamental curriculum texts, and verse composition represented the apex of learning in monastic and cathedral class-rooms of the Central Middle Ages. From antiquity, epic was considered to be the most authoritative form of poetry." The epic vita, read in the classroom, could combine the abbey's institutional history and an edifying exemplum with many of the features that made Classical epic so useful for teaching. (Taylor, 2013: 11).

They illustrate the continuity that the writers created between themselves and figures of the past (local and otherwise) and the communities they perpetuated within and beyond the cloister. They show the intertwined functions of praising the saint, flattering the patron, and educating the young (Taylor, 2013: 290). Alcuin, though certainly himself well acquainted with the principal Roman poets, in later life condemned the teaching of Pagan poetry to the Christian youth: and the tendency of the age

19 Greek mathematician, $300 \mathrm{BC}$, known as the father of Geometry.

${ }^{20}$ Gaius Plinius Secundus, (c.23-79 AD), philosopher, naturalist and writer.

${ }^{21}$ Greek Philosopher, (384-322 BC). which he inaugurates was on the whole in the same direction, though the more enlightened teachers of the Dark Ages took a more liberal view, and it is probable that in practice boys continued to be taught grammatical Latin by reading a classical author, such as Virgil or Ovid: and in the best schools, notably at Ferriéres, under Alcuin's pupil, the Abbot Servatus Lupus, a wider study of Classical literature was pursued with some enthusiasm (Rashdall, 2010: 36).

Hrabanus Maurus ${ }^{22}$ was archbishop of Mainz; he was Benedictine. He wrote treatises on education, grammar and theology. One of his most famous treatises is "On Clerical Training" which he wrote while teaching in Fulda Monastery, largely concentrates on the education of young priests. "The first part of the treatise introduced students to the Church, the ecclesiastical grades, vestments, the sacramentsespecially baptism and the Eucharist-and to the Mass. The second section provided a handy precis of the divine office, the liturgical year, feast days, hymns, the Bible, and basic prayers and blessings, and heresies. The final section outlined what priests in training ought to know, "Quid eos scire et habere conueniat, qui ad sacrum ordinem accedere uolunt." What they ought to know was, essentially, the liberal arts curriculum-grammar, rhetoric, dialectic, mathematics, arithmetic, geometry, music, astronomy, and the "philosophical" books (Sullivan, 1995: 109). Knowledge of the figures of speech as well as of the technique of constructing an argument was useful in literary exercises and treatises, but discouraged in public speech. Preachers from the time of Caesarius of Aries in the sixth century through the Carolingian period were reminded to preach in a simple, clear fashion and not to make declamations

\footnotetext{
22 Hrabanus Maurus Magnentius, (c. 780-856 AD), Frankish Benedictine monk.
} 
as if they were performing before scholars. In fact, Carolingian preachers were encouraged to use the vernacular, Thiotiscam (German) and the rustica Romana lingua, since German speakers could not understand Latin, and Romance speakers could not understand the new Carolingian pronunciation of Latin (Sullivan, 1995: 122).

After Charlemagne's death, his son Louis the Pious narrowed the range of monastic education. Anthologies of excerpts from the Church Fathers dominated the monastic curriculum, and the study of belles-lettres, Christian or secular, was discouraged (Lerner, 2009: 31). Notker of Saint Gall's guide to the foremost commentators on Scripture is another text that can stand both as a product and index of Carolingian educational practice. Notker (ca. 840912) prepared his survey of biblical exegetes for his former pupil Bishop Salomon of Constance (ca. 860-919/20). The reading program that he set out is heavily dependent on the work of the church fathers-Augustine, Jerome, and Gregory the Great-but also recommends Isidore of Seville, Alcuin, and Hrabanus Maurus (Sullivan, 1995: 110). Interest in dialectic in Carolingian schools was both deeper and wider than these seemingly isolated examples suggest. The sources for Carolingian dialectical studies were largely Claudianus Mamertus, Augustine, and Boethius. Alcuin, as he did in so many other areas of Carolingian pedagogy, oriented dialectical studies when he compiled a manual on the subject, the De dialectica which, while it derived from earlier authorities, addressed issues of particular interest to Alcuin and his circle (Sullivan, 1995: 123).

\section{OTHER AREAS OF LEARNING IN CAR- OLINGIAN MONASTERIES}

\section{1 Knowledge of Scripture}

One of the most significant aspects of monasteries was to have scriptoriums where manuscripts were copied. It required knowledge of how to make manuscript leaves and a serious instruction of scribing. Thanks to Carolingian monasteries and their scriptorias, lots of classic and new works were copied and multiplied which meant a great number of educational text and book, but the most importantly copies of the Holy Bible and Psalters could be abundant for educational use. So instruction for Scripture was held very seriously. The study and comprehension of Scripture were the ultimate goals of Carolingian education. Although modern observers of the Carolingian scene may be dazzled by the philosophic brilliance of a John Scottus Eriugena ${ }^{23}$ (ca. 810-ca. 877), the exegetical prowess of a Paschasius Radbertus ${ }^{24}$ (ca. 790-860), the poetical sophistication of a Theodulf of Orleans ${ }^{25}$ (ca. 760-821), or the classical humanism of a Lupus of Ferrieres ${ }^{26}$ (ca. 805- ca. 862), what united these scholars of different talents and interests and their confreres was the absolute centrality of the Bible in their intellectual life. Notker ${ }^{27}$ 's guide to the authorities one needed to consult to comprehend the Bible reflects the preeminence of biblical studies in Carolingian schools and the maturation of Carolingian biblical studies-a program complete with a list of authors had been erected around the Bible (Sullivan, 1995: 110).

\subsection{Christianism according to Benedictine}

\section{Rule promoted by Benedict of Aniane}

\footnotetext{
${ }^{23}$ Irish theologian, poet, philosopher. He was neoplatonist.

${ }^{24}$ Frankigh theologian, abbot in the monastery of Corbie.

${ }^{25}$ Bishop of Orleans, writer, poet.

${ }^{26}$ Abbot in the Ferrières, Benedictine monk.

${ }^{27}$ Known as Notker I, Notjer the Poet, Nother the Stammerer, (c. 840-912 AD), author, poet, musician and Benedictine Monk in St. Gall Abbey.
} 
In the early ninth century, during the fourteenyear reign of Emperor Charlemagne, Benedict of Aniane (750-821), sometimes called "the second St. Benedict," adopted a strict observance of the Rule in his monastery in southern France. Benedict, having served earlier both in the military and in the court of Charlemagne, during which time he became a monk, was now called upon by Charlemagne to lead a monastic reform in his region of France according to his strict observance of the Rule (Robinson, 2010: 9). With respect to learning, Carolingian monasticism differed markedly from that in Benedict's time. Benedict attached no particular significance to intellectual activity or the monastic schools: according to his prologue, monastic life itself was the 'school of the service of the Lord.' By the ninth century, however, the study and production of texts had assumed paramount importance in the cloister (McKitterick, 1994: 637). Opus Dei (prayer), the liturgical function of the monks was seen such a significant matter in the monastic circles that it required a high level of discipline within the monastery.
The Rule of Saint Benedict consisted of a prologue and 73 chapters (some only a few sentences long), which set out the ideal of monastic life. Monks (brethren) were to live a family life in community under the direction of a freely elected father (the abbot) for the purpose of being schooled in religious perfection (Cunningham \& Others, 2013: 250). The Rule of Benedict was impersonal and it imposed a life devoted to monastic life and lacked any possibility of returning to the world. Below one can see the density of a day in an oblate's or a monk's life which includes almost 8 hours a day. The Rule of Benedict was like a balancing phase between the strict end of Monasticism at East and the newly Europeanized Monasticism in the west. It lessened the manual and physical labor, duration, amount and the excessive burden of the prayer and though not planned, spared some space for the intellectual thrive of the people in monastic circles in the ninth century. Below one can found a daily schedule in an early medieval monastery which was quite hectic during the night time before the acquisition of his Rule.

\section{Horarium Monasticum \\ 2.00 A.M. Rise \\ 2:10-3:30 Nocturns (later called Matins; the longest office of the day) \\ 3:30-5:00 Private reading and study \\ 5:00-5:45 Lauds (the second office; also called "morning prayer")}

5:45-8:15 Private reading and Prime (the first of the short offices of the day); at times, there was communal Mass at this time and, in some places, a light breakfast, depending on the season

8:15-2:30 Work punctuated by short offices of Tierce, Sat, and None (literally the third, sixth, and ninth hours)

2:30-3:15 Dinner

3:15-4:15 Reading and private religious exercises

4:15-4:45 Vespers-break-Compline (night prayers)

5:15-6:0o To bed for the night

Figure 3. Monastic Timetable. Cunningham \& Others, (2013: 250).

\section{DISCUSSION \& CONCLUSION}

Although Charlemagne was a member of a barbarian clan and didn't have a lot at hand to compose a vast intellectual background, he made use of what he descended from his father Pippin the Short: the monasteries; he imple- 
mented his own educational zeal as a policy for renovating the state and one of its most prominent parts: the clergy. Reading all the information above one can deduce that education of Carolingian clergy was dealt with considerable care. Because it was the clergy who prayed in the name of the people and it mattered how they did it. If there was a community in the empire which was crucial after the courtiers and the military it was the clergy. Another deduction could be that education was mostly dominated by theology which means all of these efforts was to promote a vocational branch of education. Studies conducted within such a context have provided cogent demonstrations of the unique and distinctive characteristics and accomplishments of the Carolingian cultural effort. Equally important, this line of investigation has established the grounds upon which Carolingianists could claim that their era left a significant Nachleben giving shape to post-Carolingian intellectual and artistic life in Western Europe (Sullivan, 1995: 57). So despite the few numbers of the Classical works in manuscripts and the lack of educational environments in the nearby places of western Europe, present day parts of Frank Empire owes a lot to what the literature pronounces about Carolingian contribution to the European intellectual heritage today. But apparently it wasn't a tremendous success in the long run as stated within the article itself, along with the reign of his Charlemagne's son, Louis the Pious all these efforts started to lose their prominence. For example, in the synods of 816 7 he ordered the cancellation of the schools in monastic complexes where lay boys were instructed. Under the light of all and looking at the literary genres and types studied we can state that Carolingians were educating their clergy dependant on the tradition, mostly on intellectual heritage of classic texts, works and chants they inherited. Treatises, epic viteas and poetry constituted a significant part of literature for instruction. It seems that the Benedictine Rule was like the law for every systematic part or process in a Carolingian monastery and the tutelage of the generations to become clerics. And apparently the elder was highly respected and they are never useless even in the old age and that age didn't mean rank within the cloister as whoever came first and progressed is fairly more respected. Even a child oblate could be superior to a recently joined adult novice. If the Carolingian empire and civilization had survived and continued to flourish, a period of original work would doubtless have eventuated at length; but actually it was destined to be submerged in the Dark Ages and there would be need of another renaissance before the medieval period of positive, constructive and original work could be realized (Copleston, 1950: 110). Along with Charlemage, Alcuin obviously was the name who contributed most to the process. Thanks to him and the names like Notker, Hrabanus Maurus, etc. Carolingians raised the number of texts which could be left to the following generations, in short the number of written texts got higher in number. Carolingian renaissance, which also altered the instructive processes in monasteries thanks to Alcuin and his regulations on educational circles including the monasteries, could not strive at all or in other words; lived at its utmost during the synergy between Charlemagne and Alcuin but in the following periods it all vanished and could not compete with the Darkness of the Middle ages, Dark Ages itself. All these were to some extend due to the chaos run by the famous "feudalism." We can, at an extreme edge, claim that Carolingian efforts were indeed unique in sense of being a distinctive renaissance in the renovation of the cleric education. But it all happened so effectively and died off so soon within its scope. And although they were separate units with their own admin- 
istration and monopoly in the policy of determining the certain educational decisions, monasteries also must have been affected by the pitfalls and the imperial decline of the following centuries. To sum up, it was the monasteries which embodied the highest level of education one can get at the time (Trivium \& Quadrivium) and they served to the production of manuscripts which is a highly important con- tribution to the educational literature and higher studies at the time. So at some point, we can deduce that theological tutelage was prominent at the time and European higher education owes a lot to Carolingians for preserving certain level of information, as the university system of our present day emerged from monastic and cathedrical education.

\section{Referances}

Barber, J. (2008). The Road from Eden: Studies in Christianity and Culture. California: Academica Press, LLC.

Bernhardt, J. W. (2002). Itinerant Kingship and Royal Monasteries in Early Medieval Germany, c. 9361075 (Vol. 21). Cambridge: Cambridge University Press.

Carlbach, E. (2011). Palaces of Time. Canada: Harvard University Press.

Clark, J. M. (1926). The Abbey of St. Gall as a Centre of Literature and Art. Cambridge: Cambridge University Press.

Copleston, F. (1950). History of Philosophy (Vol. 2). New Jersey: Paulist Press.

Cordasco, F. (1976). A Brief History of Education: A Handbook of Information on Greek, Roman, Medieval, Renaissance, and Modern Educational Practice (No. 67). Rowman \& Littlefield.

Corradini, R., Diesenberger, M., Reimitz, H. (2003). The Construction of Communities in the Early Middle Ages: Texts, Resources and Artifacts. Leiden: Brill.

Cross, F. L., \& Livingstone, E. A. (2005). The Oxford Dictionary of the Christian Church. New York: Oxford University Press.

Cunningham, L., Cunningham, L. S., \& Reich, J. (2013). Culture and Values : A Survey of the Western Humanities (8th ed.). Thomson Wadsworth

Dales, R. C. (1973). The Scientific Achievement of the Middle Ages (Vol. 57). University of Pennsylvania Press.

Deanesly, M. (1969). A History of the Medieval Church: 590-1500. London: Routledge.

De Jong, M. (1996). In Samuel's Image: Child Oblation in the Early Medieval West (Vol. 12). Leiden: Brill.

Ferzoco, G., \& Muessig, C. (Eds.). (2001). Medieval Monastic Education. London/New York: Leichester Univesity Press

Greene, J. P. (1992). Medieval Monasteries. London: Continuum International Publishing Group.

Grotans, A. A. (2006). Reading in Medieval St. Gall. Cambridge: Cambridge University Press.

Hildebrandt, M. M. (1992). The External School in Carolingian Society (Vol. 1). Leiden: Brill.

Jaeger, S. (1994). The Envy of Angels: Cathedral Schools and Social Ideals in Medieval Europe, 950-1200. Univ. of Philadelphia: Pennsylvania Press.

Lerner, F. (2009). The Story of Libraries: From the Invention of Writing to the Computer Age. New York: Continuum International Publishing Group.

McKitterick, R. (Ed.). (1994). Carolingian Culture: Emulation and Innovation. Cambridge: Cambridge University Press.

(1995). The New Cambridge Medieval History II c.700-c.900. Cambridge: Cambridge University Press. 
Moffett, M., Fazio, M., \& Wodehouse, L. (2003). A World History of Architecture. London: Laurence King Publishing.

Rashdall, H. (2010). The Universities of Europe in the Middle Ages: Salerno. Bologna. Paris. Cambridge: Cambridge University Press.

Riché, P. (1978). Daily Life in the World of Charlemagne. University of Pennsylvania Press.

Robinson, D. (2010). Ancient Paths: Discover Christian Formation the Benedictine Way. Massachussetts: Paraclete Press.

Sullivan, R. E. (1995). The Gentle Voices of Teachers: Aspects of Learning in the Carolingian Age. The Ohio State University Press.

Taylor, A. L. (2013). Epic Lives and Monasticism in the Middle Ages, 800-1050. New York: Cambridge University Press.

Verhulst, A. (2002). The Carolingian Economy. Cambridge: Cambridge University Press. 


\section{Genişletilmiş Özet}

Manastırlar tarih boyunca dini karakterlerinin yanı sıra birer eğitim kurum olma özeliği de taşımış ve Hristiyanlığın doğuşundan sonra özellikle de Orta Çağ Hristiyan Avrupa'sının eğitim tarihinde önemli yer tutmuşlardır. Manastırların ilk olarak Hristiyan keşişlerler çöl hayatında dayanışma içinde yaşamaya başladığında, 4. yüzyılda Mısır'da ortaya çıktığı bilinmektedir. Mısır'da başlayan bu mevhum Avrupa'ya da yayılmıştır. Orta Çağ Avrupa'sında manastırlar hükümdarın olduğu kadar halkın gözünde de çok önemli bir yer tutardı çünkü kendileri için Tanrı'ya yakarıp dua eden yani dini ritüelleri gerçekleştiren ruhban sınıfı manastır kökenli idi ve bu grup teolojik meselelerde hükümdara danışmanlık yapardı. O dönem diğer Avrupa hanedanlıklarında olduğu gibi Karolenj hanedanlığında da ruhban sınıfı dolaylı da olsa siyasi ve dini alanda erk sahibi idi ve bu sınıfa dahil olmak prestij demekti. Din adamları için 8. Yüzyıl'da Karolenj hanedanına mensup Kral Şarlman yönetimi altında Nurthambria'lı İngiliz bir akademisyen olan Alcuin'in yönettiği entelektüel bir yenilenme hareketi başlatıldı. Şarlman ve Alcuin yönetimde oldukça kapsamlı bir reform başlattılar ve ruhban sınıfı da bu reformlardan eğitsel ve bilgilendirici eğitim süreçlerinin yenilenmesi bakımından etkilendi. Ruhban sınıfı Orta Çağ Avrupası'ında oldukça yetkindi; manastır çevreleri ekonomik açıdan neredeyse otonom gibiydi ve krala karşı sorumluyuı. Toplumda yüksek prestij sahibi olan başkeşişler tarafından yönetilen bu eğitim kurumları, öğretimin teolojiye yani Hristiyanlığa dayalı da olsa programlı ve sistematik hale geldiği (katedral ve kilise okulları karakterine sahip) tek kurumlardı. Şarlman'ın bu girişiminden önce, eğitim karakteristik olarak yerel kiliselerde rahiplerin verdiği temel dini bilgilerden, ayin bilgisi ve klasik eserlerin okunuşundan ileri gitmiyordu. Şarlman ve Alucin'in yayınladığı bildirgelerle birlikte müfredatta değişiklikler yapıldı ve Karolenj manastırlarındaki eğitim kadar saray okulundaki eğitim de değişikliğe uğradı. En önemlisi müfredata teolojik ve litürjik bilginin yanı sıra Beşeri İlimler de dahil edildi; bu dönemden itibaren Beşeri İlimlerin manastırlarda Hristiyan karakteri kazanmaya başladığı söylenebilir. Ayrıca bu dönemde manastırların planlarına vergi veren halkın çocuklarının devam edebileceği harici okullar da eklendi. Bu okullarda temel gramer, hesap, aritmetik ve ilahi eğitimleri de veriliyordu. Manastır öğrencileri Teoloji ya da Felsefe okumaya başlamadan önce Latince "Üçlü Yol Ağzı" yani Trivium (Gramer, Mantık ve Hitabet) ve sonra Quadrivium (Aritmetik, Geometri, Müzik ve Astronomi) yani "Dört Yol Ağzı" anlamlarına gelen bilimleri sırayla başarmak durumundaydı. Bu iki grup birbirinden ayrı olarak çalışılırdı; Trivium'da Gramer ve Hitabet, Mantık bilime göre daha önemliydi. O zamanda "Grammatica" olarak geçen Gramer, özellikle metinlerin doğru ve etkili bir şekilde yorumlanması ve imla ile ilgili idi. Hitabet ise dinleyicileri belirli bir konuda bilgilendirme, ikna etme, cesaretlendirme ya da motive etme üzerineydi. Karolenj manastır çevrelerinde Quadrivium yüzeysel ilgi görmüştür hatta bu hareketin mimarı olan Alcuin de çalışmalarının çoğunda Trivium'a odaklanmıştır. Diğer birçok rahip, keşiş, akademisyen ve din adamına ek olarak Alcuin gibi Hrabanus Maurus ve Notker Balbulus, diğer adı ile "Kekeme Notker" de Karolenj manastrılarının repertuarını genişleten bilimsel ve edebi eserlerler ortaya koymuşlardır. Dönem manastırlarında "scriptoria" denilen yazıhaneler de mevcuttur ve yazman rahipler ya da manastır öğrencileri bu yazıhanelerde o dönemde ulaşılması güç ve sayıca az olan klasik ve yeni eserlerin orijinal örneklerini yazı ile çoğaltmışlardır. Bu eski ve kopyalanarak çoğaltılan temel eserler Trivium ve Quadrivium bilim gruplarının eğitiminde kullanılmıştır. Günümüz eğitim sistemine bir benzetme yapılacak olursa Trivium ve Quadrivium isimli bu ikili yapıyı bir nevi Master Derecesi olarak kabul etmek mümkündür diyebiliriz. Karolenj manastırlarında eğitim sürekliydi ve eğitimcilere magistri denilirdi. Bu eğitimciler gündüz eğitim ve dini yükümlülükler, gece ayinler, manastır yaşamının gerekliliklerinin yanı sıra öğrencilerin eğitimi ile de yakından ilgilenirdi yani manastırda eğitim ve çalışma hayatı kesintisizdi. Karolenj manastırında eğitim almak ya da rahip olmak, Şarlman zamanında kabul gören Aziz Benedict Kurallarına uyulmasını gerektiriyordu fakat aynı hükümdar yönetimi altında başka aziz- 
lerin kurallarının da kabul gördüğü olmuştur. Genç bir manastır öğrencisi yeni başlayan bir yetişkinden kademe açısından daha üstün kabul edilirdi çünkü önemli olan manastırda ne kadar zaman geçirilip, ilerleme kaydedildiği idi; yaş değil. Circatores olarak bilinen yaşlı ve tecrübeli rahipler gün boyunca da manastır avlusu ve diğer alanlarda genç öğrencileri izlerlerdi. Karolenjler entelektüelizme değer vermeyen diğer barbar kavimlerden bu yönleri ile ayrılırlar. Şarlman, kendi döneminde, ruhban sınıfını yetiştiren kurum olan manastırlarda bilimsel düzey ve yüksek öğrenime -ki bahsi geçen dönem yüksek öğretime rastlaması güç bir dönemdir- etkili bir yenilenme hareketi ile oldukça katkıda bulunmuştur. Her ne kadar bu hareketler temelinde mesleki yani teolojik yöne eğilim verse ve kısa ömürlü olsa da Karolenj eğitim reformu, klasik eserlerin ve klasik döneme ait bilgi birikiminin muhafaza edilmesine, Karanlık Çağları atlatıp İtalyan Rönesansı'na kadar hayatta kalmasına büyük katkıda bulunmuştur. Bu bağlamda Avrupa yükseköğretiminin, bugün çoğu bilime temel hazırlayan klasik eseri muhafaza ettiği ve belli seviyede bilgi sürekliliğine katkıda bulunduğu için Karolenj hanedanlığına çok şey borçlu olduğu söylenebilir. 